\title{
The roofs of Istanbul's wooden houses with the influence of European styles
}

\author{
S. F. Yagci \\ Technische Universität München, Germany
}

\begin{abstract}
Turkish houses with their own characteristics related to the architectural elements and spatial construct manifest differentiating examples over the centuries. From the 18th century, traces of the European styles steadily reflected to the Turkish houses. On the period between late 19 th century and early 20th century, the effects of these styles were intense on the wooden residential architecture. With its pluralist and progressive feature, interactive relations were extensive in the last Ottoman capital Istanbul. Consequently, a great diversity in wooden houses had occurred. This variety of styles was exposed on the choices of architectural elements. Having a significant effect on both the façade image and the spatial organization, roof is one of the architectural elements expressing explicitly the European influence on the Ottoman wooden houses of Istanbul. There are many examples of roof types dissimilar to the classical Ottoman houses like pointed and steep roofs, cross or $\mathrm{T}$ shaped ones and even the roofs with curvilinear forms. Besides the distinctness in shape organizations of the roofs, the insertions of windows, balconies, ornaments and decoration elements were also developed. Another issue reflecting the western style is the tower designed with roof structure which signifies the architectural approach. Wooden houses under the effect of European styles are generally found in the country side or summer houses and the new settlements of their period. In this work, the European influence on the timber residential architecture in Istanbul with a special emphasize on the roof styles will be presented. Apart from the general information about this wooden housing heritage with different forms, structural system and usage of the materials will also be discussed.
\end{abstract}

Keywords: Ottoman wooden houses, roof, European influence, Istanbul timber houses, late 19th century. 


\section{Introduction}

The traditional Turkish house, which bears traces from Turkish society life and has its own special features with the architectural composition, changed with the effects of different styles in the last period of Ottoman Empire [1]. The timber tradition nourished by a rich local and foreign lexicon on forms, developed an eclectic style, mostly particular to Istanbul. Reflecting the cosmopolitan cultural atmosphere and pluralist feature of Istanbul, an intense style diversity was encountered [2]. Westernization took place after the Tulip Period and its effect on the wooden residential architecture had started in the 18th century. At first it appeared only with some traces and became apparent especially on the decoration manner. Later on it had an effect on the whole spatial perception. The European styles were influential on various architectural decisions like plan type, decoration style and façade design. As roofs have the sufficiency to change the perception of the façade and be coalesce with the stylistic decoration elements, they become an important part reflecting the effect of western styles on the character of the houses. The variety of the styles on the residential architecture in Istanbul was remarkable between late 19th century and early 20th century. Parallel to this diversity, the alteration on the appearance of the roofs intensify by the same period. The present paper is aimed to focus on the 'late capital style' roof types of Istanbul.

Examples of this heritage can be seen on the countryside or summer houses and the new settlements of their period. Timber houses with the roofs under the influence of European styles can be found especially in Prince's Islands, Bosphorus villages, Kadıköy district (particularly in Göztepe and Erenköy) and Yeşilköy. Therefore, evaluated timber houses within the scope of this work are mainly chosen from these regions. In this context, it is worth to mention that timber houses with the roofs, which are differentiated from classical Ottoman style can also be encountered in other districts but their number is very limited.

Mainly the traces and interpretations of the forms baroque, rococo, empire, neo-gothic, neo-classic, neo-Greek and art-nouveau are come across on the timber houses. Moreover, English Victorian style and Swiss cottage style mansions were also built [3]. The effect of orientalism, basically taken from the interpretations of Europe, was used in the same period [4]. In addition to those houses; eclectic buildings, combining the elements of several styles are also present. The reflection of the different styles can be seen on the roof types as well. While some of the styles are affecting the roofs in a figural way, some others are expressed only on the architectural elements or ornaments which are incorporated into the roof. Within this work, the distinction on the appearance of the traditional timber Turkish house's roof by the 19th century will be exposed.

\section{Forms of the roofs}

Simplicity was the character of the Turkish timber roof system and complicated roof forms corresponding to the expression of the house plans were never developed. The preferred form on the traditional Turkish timber house was hipped or gable roof, or a combination of the two [5]. While the combination form and 
hipped roof were popular in mansions, gable roof was mostly preferred in contiguous buildings. With the increasing interest on the European styles after the 19th century, diversified examples of the roof forms, different from the common ones of the traditional Turkish house, came in sight. These forms, having a new sense of visual impact were implemented on the Ottoman timber houses through the skills of the craftsmen and desires of the house-owners.

As an almost never encountered feature on the houses of the previous periods, the curvilinearity brought a new approach to the last period residences of Ottoman Empire. S and C figures of the baroque and rococo styles are seen with different combinations in the roofs, especially in eaves, of timber houses. The curvilinearity on the roofs are found in both horizontal and vertical planes. Rounded forms in horizontal plane were often used to cover the curved lines of the plan. Several roof models giving the impression of a curved part are actually composed with the combination of wide angled straight lines or a polygon. These types of roof structures were constructed relatively similar to the classical timber houses. When the curves in horizontal plane takes place in the plan of the design, the curvilinearity is sensed from the inner side. Additionally, the curved forms in the horizontal plane were also used on the eaves of a cornered mass (Figure 1). The arched forms in the parallel line were specifically used for the part of a building as there exist no totally round shaped timber house or roof. Another usage of the timber curvilinear forms was in the vertical plane of the houses. This type of curved forms were used as a decorative element to display and enliven the façade. Thus, they constantly appeared in sight on garish frontal façade of the building (Figure 2). These curves were also prevalently seen on the eaves or only part of the roof in a similar manner to the curvilinear forms in horizontal plane. However, the curvilinear forms in vertical plane usually create more cleancut and explicit curve than forms in horizontal plane. In addition, it has to be mentioned that arches with different radius and dimensions are existing.
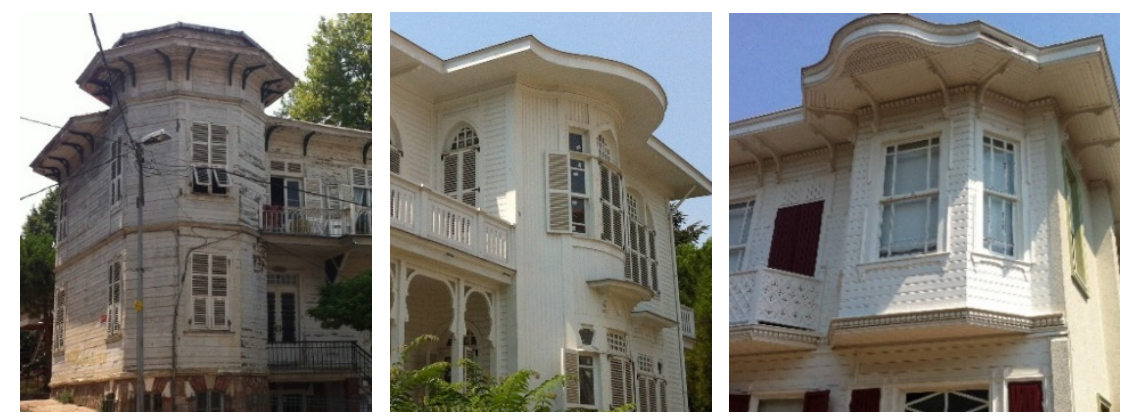

Figure 1: Different types of arched forms in horizontal plane. 

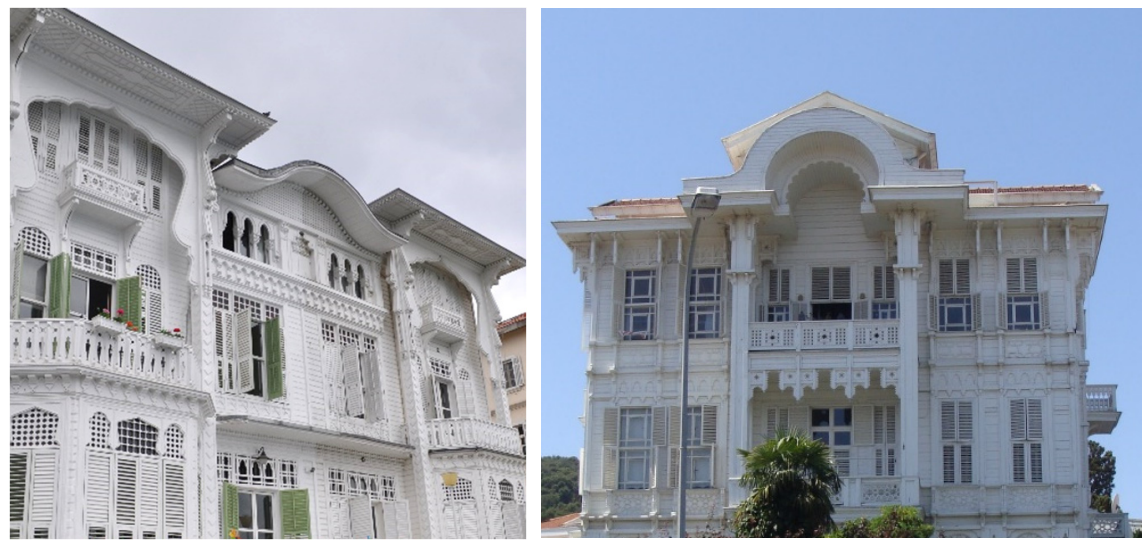

Figure 2: $\quad$ Usage of curvilinear forms on vertical plane.

Utilizing the roof with different levels was a common preference on the same period (Figure 3). With the elevated position of a part of the roof, a new space was created. The elevated mass could be a rectangle, as well as T shaped or crosssimilar form. Various housing types were obtained with the belvederes and differentiated sloops. Several components of European styles were involved in these examples. It needs to be clarified that, the presence of different levels in the roofs of early periods is different than the examples designed under the European influence. By the examples from earlier periods the differentiated level of roofing was usually built to cover the oriel and the roof had an integrated approach. Though, the darting blocks in the roofs of the late period examples became flourishing elements for the building.

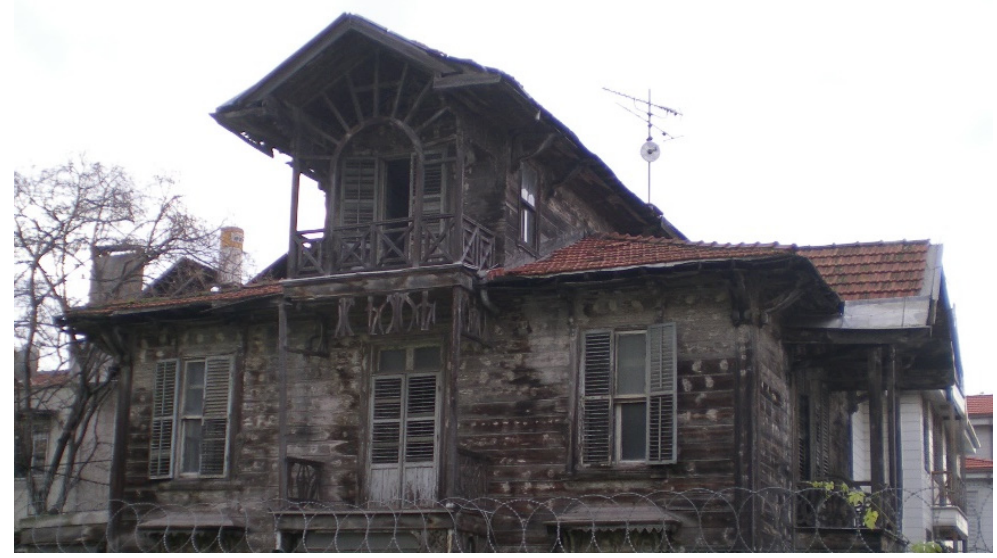

Figure 3: Utilization of a roof with different levels. 
Another key point that creates the differentiation in the roofs is the roof pitch. After the 19th century steeply pitch roofs, inspired by the Swiss chalet or Austrian mountain houses took place in the Istanbul's timber housing architecture. Although the presence of pitch roofs in Istanbul before the 18th century is a matter of debate [6], it is obvious from the extant buildings and old photos that the pitch roofed houses built after the westernization period were distinguished from the examples of 18th century. In conjunction with the increased slope, an opportunity to create a new living space in loft was provided. Then, it brings along the openings like window or balcony resulting in the complete change of the roof structure. The house in Buyukada Kadiyoran street (see fig. 4), which has similarities with Olbrich's "Hermann Bahr House" in Vienna [7], and tower of the yalı of Mahmud Nedim Pasha, who was a legate of Vienna $[8,9]$, are examples with steeply pitched roof. Especially, in Buyukada and Kadıköy there are several examples similar to Swiss style or English Victorian style, which has steeper-pitch structured roof than the classical Ottoman house. Moreover, in some houses steep pitch was not used in the whole structure of the roof but only to strengthen the decoration (Figure 5). Also, some other typical decoration or architectural elements of a style were placed in a certain part of the roof to have a luxurious view. Positioning an element from Neo-classic or Neo-Greek style like "fronton" above the oriel changes the general impression of the roof remarkably (Figure 6). In addition to those styles, although mansard roof is a foreign form to Istanbul, it was adopted and used in some houses [3]. Half-hipped roofs, which are very common in Germany, Denmark and Austria, were also represented in the timber heritage of Istanbul with a few examples.

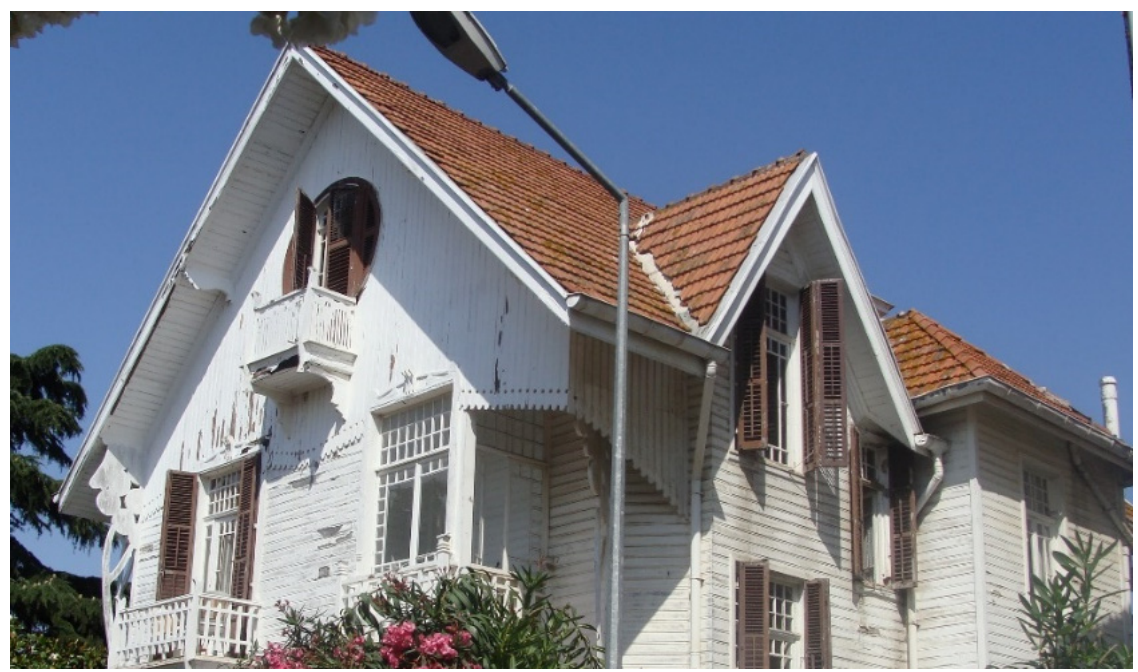

Figure 4: $\quad$ Steeply pitched roof example from Buyukada. 


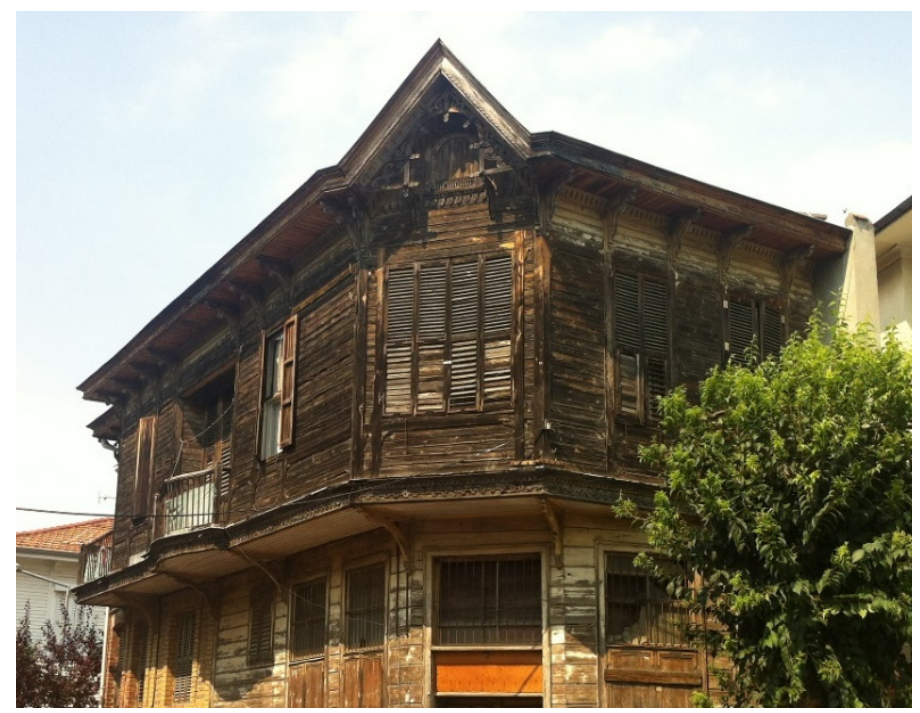

Figure 5: $\quad$ Steep pitch as a part of decoration of the façade.

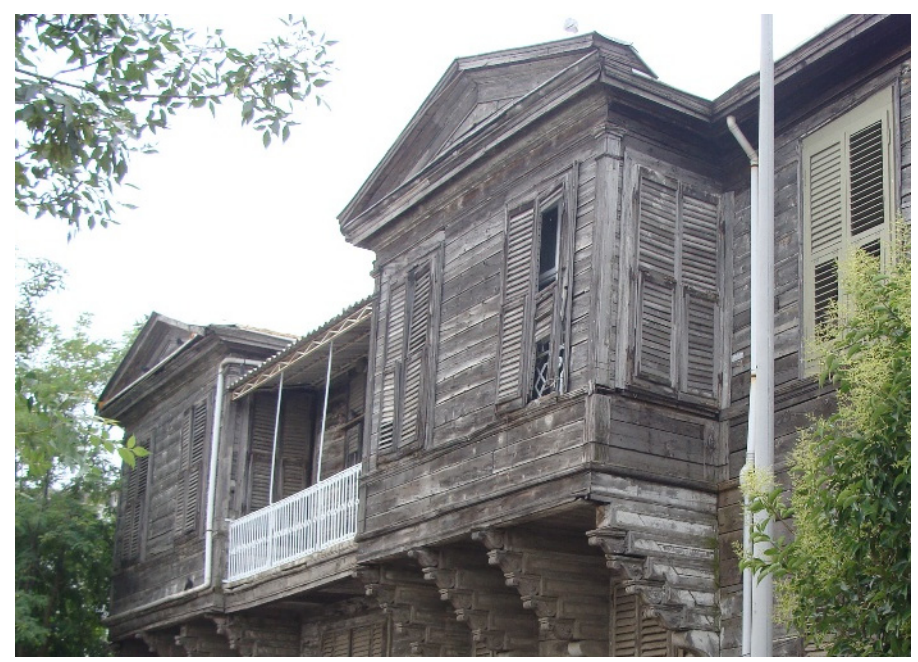

Figure 6: Fronton above the oriel.

Lastly, there are numerous unique houses that the multiplicity of stiles cannot be categorized. These are the eclectic buildings, which have traces from more than one approach or style. Right along with the European influences, the usage of the orientalist approach on the roof structures can be mentioned. In a number of timber residences, like yalı of Afif Pasha and mansion in Sariyer Orta Cesme street, a bulbous dome is placed above the tower or oriel rising as if tower (see also fig. 9 in section 3.4). 


\section{Elements effecting the roof}

Besides the main layout of the roof structure, the appendant elements have also an effect on the view and form. Some notable figures of the styles were not used to cover all the structure but they were revealed in small interferences. Elements that cannot be constituted as a whole roof construction by itself but playing a crucial role in the roof perception are depicted below.

\subsection{Decoration elements and ornaments}

Decorative ornaments shown on façade also take place in the roof and eaves with various compositions, reflecting influences of different styles. (Figure 7) As an example, while the decorations with $\mathrm{S}$ and $\mathrm{C}$ figures were used in the roof of a baroque or rococo building, pointed arches and spires were seen in the neo-gothic houses. Victorian age, cottage style, chalet, carpenter's gothic were also represented in decoration elements of the timber houses. As representative features of these styles, arrow placed on the ridge of a steep roofed house and with scallops and latticework ornate eaves were often encountered [3].

Moreover, curvilinear details and striking brackets were utilized to decorate the roofs of timber houses. Fully cantilevering over superbly sculptured brackets and geometric decoration of the eaves were influenced mostly by Art Nouveau design, which was a very popular style on that period. In addition, it has to be pointed out that Kuban drawn attention on the richly decorated eaves as one of the characteristic features of the mansions of the period between late 19th and early 20 th century. He also emphasized on the amusing three dimensional touch of these decorations to the residential architecture of Istanbul [5].

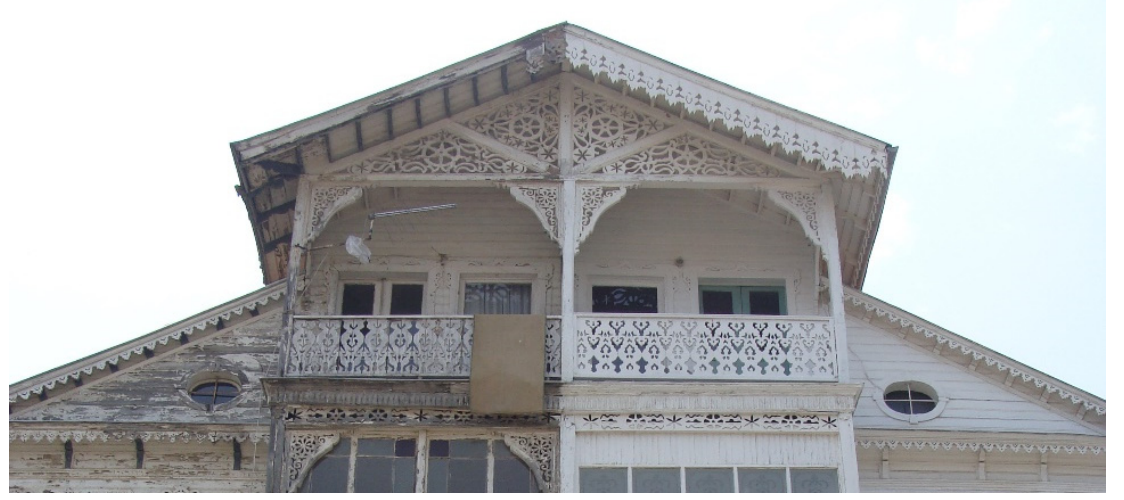

Figure 7: Timber double house with ornaments. 


\subsection{Roof windows}

As steep-sloped roofing gives an opportunity to create a living space immediately under the roof deck, it brings the need of roof windows to meet the need of light and fresh air to the attic. The windows on the roofs appeared as the created lighting as part of the structure, but also as an additional glossy segment incorporated to the roof (Figure 8). Roof windows were built in various shapes like oval, rectangle or arched form.

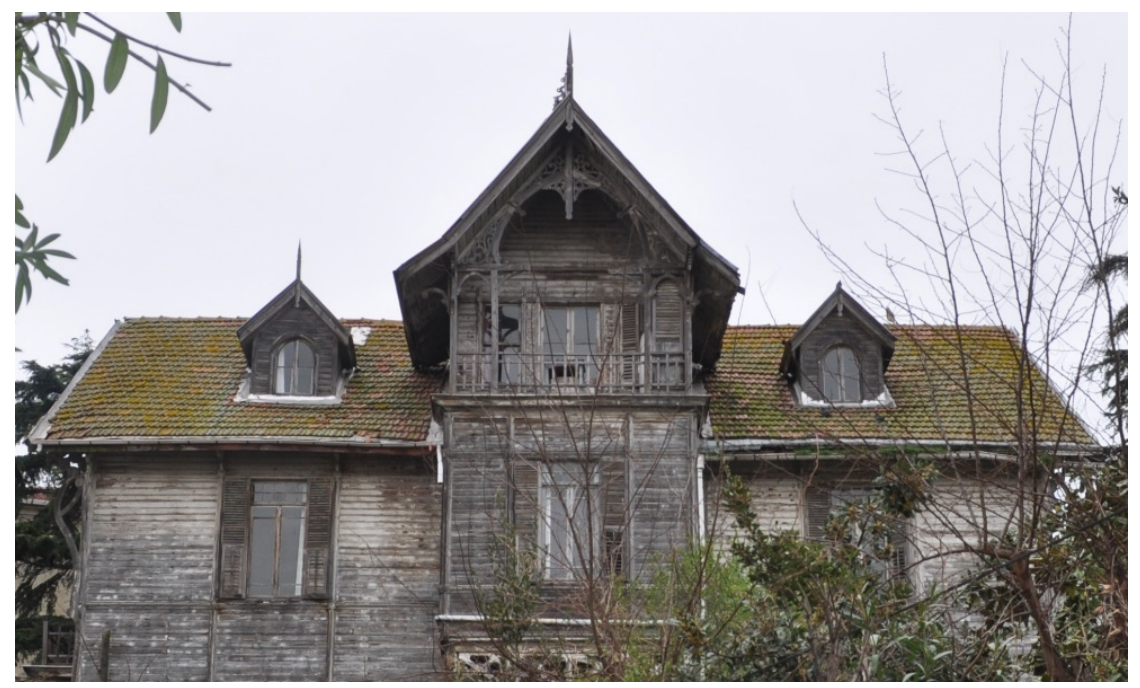

Figure 8: Roof windows and ornaments of a timber house in Buyukada.

\subsection{Balconies}

Introverted way of life was dominant in the traditional Turkish house structure and there were limited solutions to the outside relationships [10]. Interactions with the street life were obtained with oriels and bay windows, instead of balconies. Thus, the usage of a balcony on a garret was accrued after the interpretation of western styles into the Turkish house. Balconies are found in various roof shapes enabling a living space in attic. As almost all of the roof-balconies were decorated with several ornaments, reflecting significant emphasize on the effect of the belonged style.

\subsection{Tower}

Tower was not a part of the architectural elements of the Turkish timber residential architecture until the mid-19th century. With the influences of western buildings, craftsmen adapted it to the timber heritage of Istanbul. Towers were mainly built for spacious cottages, mansions and yalis, which were located in the country side, as summer place and new residential districts of that period which were generally 
used by the upper-class. It was unconventional to design an attached timber house in the inner-city of late 19th century with a tower. Generally towers were preferred to be located in a corner of the house. The ones placed just below the house, had its own solution for the plan and roof configuration. Yali (seaside mansion) of Muazzez Hanım in Cengelkoy is an example of the houses with tower. Besides, there is another tower-alike shape, which looks like an annex on the roof structure. These type of form starts from an upper floor or the block transforms into a tower form just with its head piece (Figure 9).

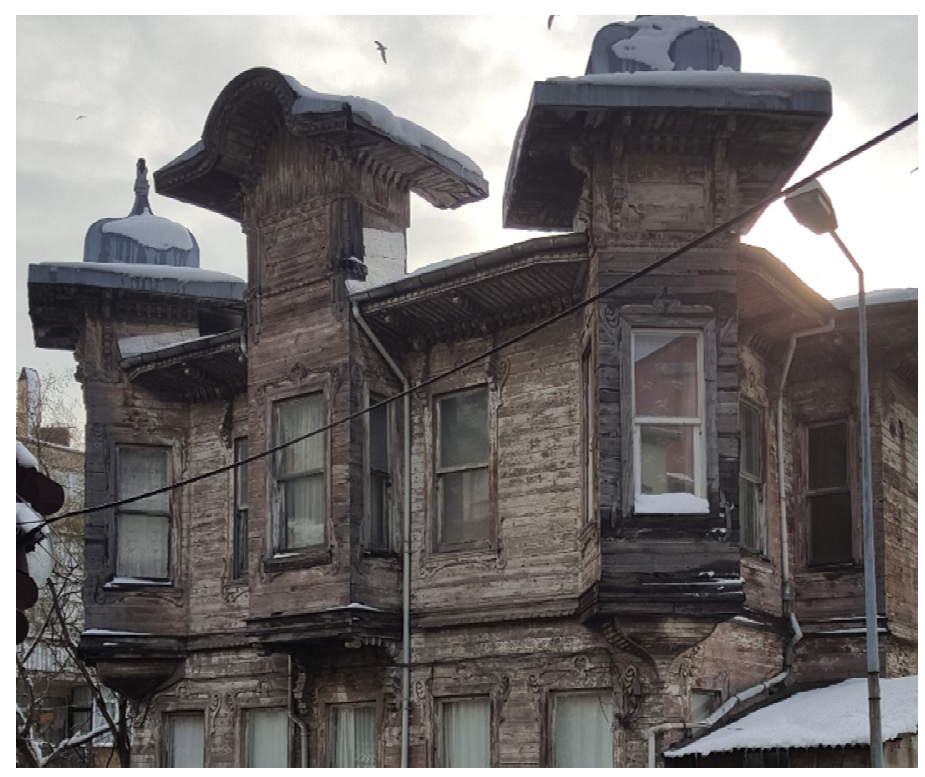

Figure 9: Transformation of the oriels above the roof structure.

\section{Material and structure}

Tile as being the typical roof cover of the traditional Turkish wooden house, continued to be used also in the last period of Ottoman Empire. While the underoverlap tiles were commonly used as a roof cover of the wooden houses, industrially made groove tiles were introduced to Ottoman residential architecture at the end of 19th century. Rapid popularity of the industrial groove tiles may be related to the heavy weight and problems associated with the maintenance of the under-overlap (alaturca) tiles. These new type of tiles were mainly imported from Marseille and therefore still named as "Marsilya tiles" in Turkey [11]. From place to place the under-overlap tiles are still encountered today. Thus, it proves that both types of tiles were used in the period between late 19th century and early 20th century. In addition to that, some other materials like zinc and lead might have been used especially in the variant shaped roofs, which would be troublesome to cover with tiles. 
While the eye-catching view of the roofs, the inner structure was not paid special attention. As the simplicity was the dominant character of the traditional housing, the constructive timber elements were used within the frame of pragmatism. Common traditional timber frame technique was repeated also in the timber houses under the influence of European styles (Figure 10). Simple joinery methods were used and wooden pieces were nailed to each other in the connection points.

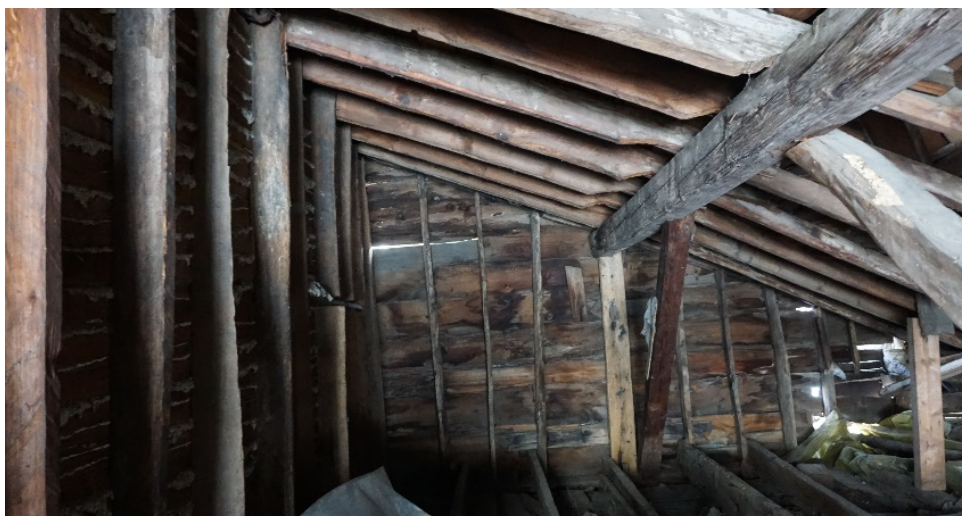

Figure 10: Inner sight of a timber house with ornamented roof.

Although the construction of the roofs has a major importance for the wooden houses, only limited information is available. Bachmann claims that the deficiency of documentation is in a consequence of the difficulties for accessing the roof structure [11]. Another reason might be the lack of authenticity, as the roofs are usually the first part of the house to be renewed due to their direct contact with weather conditions. Extended studies about the construction of the roof from the period between late nineteenth century and early twentieth century are being processed by the author.

\section{Conclusion}

The diversity of the styles encountered on the timber residential architecture in Istanbul after the late nineteenth century was also explicit on the roof types. With the influence of European styles, there had been a fundamental change on the traditional Ottoman timber houses and the foreign appearance of the roofs had an important effect to intensify this approach. As the form multiplicity is extensive and decoration features from some different styles are nested, it is not easy to build up categories covering all the roofs. Besides the variation in the roof forms, the appendant elements also played a curial role in the changed roof perception. Therefore, these aspects are investigated separately. Various roof forms are described in detail with examples and the main elements exposing European styles are listed. Presenting the multiplicity on the roofs of Istanbul's timber houses is 
the focal point of the research, but the covering material and structure are also briefly mentioned.

It soon become evident that the information about the roof types in Istanbul after the late nineteenth century is very limited. Although the change of traditional house under European influence is known and the styles were scarcely touched in a few study, the corresponding comparative comprehensive analysis for the roofs has not been reported. Especially, the structural system of the roofs from that period needs more detailed investigation, as the number of authentic examples are gradually decreasing [12]. To make accurate evaluations for the Turkish wooden house architecture, it is important to exhibit the changes with influences and find out the preserved main classical features of this significant heritage.

In summary, the extensive variety of timber structured roofs in the last capital of Ottoman Empire after the westernization were exposed in the present study. Traditional Turkish house carries traces from the social life of Turks and this variety on the last period of the empire gives information about the pluralist atmosphere of the nineteenth century and the relationship with Europe. As being one of the distinctive studies focusing on the changes in the roofs of Istanbul's traditional wooden houses, it is expected that this work will be a basic guide for further research.

\section{References}

[1] Eldem, S. H., Turkish Houses Ottoman Period, T.A.Ç Vakfi: Istanbul, Volume: I, 1984

[2] Kuban, D., Wooden Housing Architecture of Istanbul, Wooden Istanbul: Examples from Housing Architecture, ed. M. Bachmann \& M.B. Tanman, İstanbul Research Institute Cataloges: Istanbul, pp. 14-17, 2008

[3] Saner, T., Style and Character in the Wooden Housing Architecture of Istanbul, Wooden Istanbul: Examples from Housing Architecture, ed. M. Bachmann \& M.B. Tanman, İstanbul Research Institute Cataloges: Istanbul, pp. 64-89, 2008

[4] Saner, T., 19. Yüzyıl İstanbul Mimarlığında “Oryantalizm”, Pera Turizm ve Ticaret A.Ş: İstanbul, 1998

[5] Kuban, D., The Turkish Hayat House, Eren Yayınc1lik: Istanbul, 1995

[6] Cerasi, M., The formation of Ottoman house types: a comparative study in interaction with neighbouring cultures. Muqarnas, 15, pp. 116-156,1998

[7] Barillari D. \& Godoli E., Istanbul 1900:Art Nouveau Architecture and Interiors, Rizzoli: New York, 1996

[8] Erdenen, O., Boğaziçi Sahilhaneleri 2, Istanbul Buyukşehir Belediyesi Kültür İşleri Dairesi Başkanlığı Yayınları: Istanbul, Volume 12, pp. 261263, 1993

[9] Kayra, C. \& Uyepazarci E., Mekanlar ve Zamanlar Kandilli-VaniköyÇengelköy, Istanbul Buyukşehir Belediyesi Kültür İşleri Dairesi Başkanlığı Yayınları: Istanbul, Volume 13, pp. 110-111,1993

[10] Kucukerman, O., Turkish House in Search of Spatial Identity, Turkish Touring and Automobile Association: Istanbul, pp. 51-53, 1991 
208 Islamic Heritage Architecture and Art

[11] Bachmann, M., The Technical and Constructive Characteristics of the Wooden Houses of Istanbul, Wooden Istanbul: Examples from Housing Architecture, ed. M. Bachmann \& M.B. Tanman, İstanbul Research Institute Cataloges: Istanbul, pp. 20-62, 2008

[12] Yagci, S. F. \& Mazlum D., Traditional Timber Houses of Istanbul: Heritage Values and Preservation Problems, Journal of Architectural Conservation. 2016 (in press) doi:10.1080/13556207.2016.1139853 